\title{
Crossing of the intestinal barrier by HTLV-1 infected lymphocytes
}

\author{
Florent Percher ${ }^{1,2,3}$, Patricia Jeannin ${ }^{1,2}$, Pierre-Guillaume Deliège ${ }^{1,2}$, Antoine Gessain ${ }^{1,2}$, Aurore Vidy-Roche ${ }^{1,2}$, \\ Philippe V Afonso ${ }^{1,2}$, Pierre-Emmanuel Ceccaldi ${ }^{1,2,3^{*}}$ \\ From 17th International Conference on Human Retroviruses: HTLV and Related Viruses \\ Trois Ilets, Martinique. 18-21 June 2015
}

In several areas of high endemicity, HTLV-1 can be transmitted from mother to child, through prolonged breast-feeding. This way of transmission is particularly linked to the development of Adult T Cell Leukemia (ATL). In this context, we studied the mechanisms of HTLV-1 transmission through the digestive tract. We previously demonstrated in an in vitro model of compartimentalized co-culture device of human enterocytes, lymphocytes and dendritic cells, that HTLV-1 was unable to infect enterocytes, or disrupt tight cell junctions, but could rather be transported by transcytosis to infect sub-epithelial dendritic cells (Martin-Latil et al., Blood, 2012). Since HTLV-1 infection has been shown to be more efficient through cell-associated virions, we also focused on the crossing of HTLV-1 infected lymphocytes through the intestinal barrier. We thus studied the migration of HTLV-1 infected lymphocytes across the intestinal epithelium, both ex vivo (on intestinal explant model) and in vitro (on a monolayer of human enterocytic cell line cultured on Transwell devices). We demonstrate that, in both systems, infected lymphocytes are able to cross the epithelial barrier, with increased capacities compared to uninfected lymphocytes. Our work suggests that HTLV-1 infected lymphocytes efficiently cross the intestinal barrier, which could constitute an additional way for mother to child HTLV-1 transmission during breast-feeding.

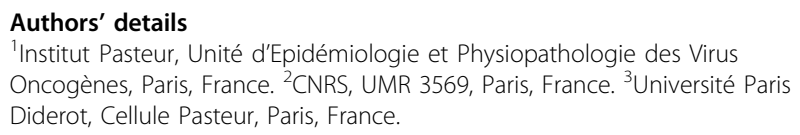

* Correspondence: pierre-emmanuel.ceccaldi@pasteur.fr

${ }^{1}$ Institut Pasteur, Unité d'Epidémiologie et Physiopathologie des Virus

Oncogènes, Paris, France

Full list of author information is available at the end of the article
Published: 28 August 2015 doi:10.1186/1742-4690-12-S1-O33
Cite this article as: Percher et al.: Crossing of the intestinal barrier by
HTLV-1 infected lymphocytes. Retrovirology 2015 12(Suppl 1):O33.
Submit your next manuscript to BioMed Central and take full advantage of:

- Convenient online submission

- Thorough peer review

- No space constraints or color figure charges

- Immediate publication on acceptance

- Inclusion in PubMed, CAS, Scopus and Google Scholar

- Research which is freely available for redistribution

Submit your manuscript at www.biomedcentral.com/submit

\section{Biomed Central}

C Biomed Central

(c) 2015 Percher et al. This is an Open Access article distributed under the terms of the Creative Commons Attribution License (http:// creativecommons.org/licenses/by/4.0), which permits unrestricted use, distribution, and reproduction in any medium, provided the original work is properly cited. The Creative Commons Public Domain Dedication waiver (http://creativecommons.org/publicdomain/ zero/1.0/) applies to the data made available in this article, unless otherwise stated. 